\title{
CHANGING TRENDS OF PHYSICOCHEMICAL PARAMETERS IN KAPTAI LAKE OF BANGLADESH
}

\section{Md. Abul Bashar*, S Sanjib Basak, Kazi Belal Uddin, AKM Saiful Islam and Yahia Mahmud}

Bangladesh Fisheries Research Institute, Riverine (Lake Fisheries), Sub-station, Rangamati-4500, Bangladesh

*Corresponding author: Md. Abul Bashar, E-mail: mabashar.bfri@gmail.com

\begin{tabular}{|c|c|}
\hline ARTICLE INFO & ABSTRACT \\
\hline Received & Physicochemical parameters were studied for a period of two years from July 2012 to J une \\
\hline 02.06.2015 & $\begin{array}{l}\text { 2014. The parameters namely air and water temperature were estimated using centigrade } \\
\text { thermometer, transparency using secchi disc while } \mathrm{pH}, \mathrm{CO}_{2} \text {, total hardness, total alkalinity, } \\
\text { dissolved oxygen }(\mathrm{DO}) \text { were estimated using } \mathrm{HACH} \text { water test kit. The highest air and water } \\
\text { temperature }\left(31.52^{\circ} \mathrm{C} \text { and } 30.38^{\circ} \mathrm{C}\right) \text { were recorded in September, } 2013 \text { whereas the lowest air }\end{array}$ \\
\hline 28.08.2015 & $\begin{array}{l}\text { and water temperature } 21.04^{\circ} \mathrm{C} \text { and } 20.42^{\circ} \mathrm{C} \text { were recorded in January, } 2014 \text {. The } \mathrm{pH} \text { of } \\
\text { water was found to alkaline in nature }(6.9 \text { to } 8.20) \text {. The maximum free } \mathrm{CO}_{2} \text { value }(7.81 \mathrm{mg} / \mathrm{l})\end{array}$ \\
\hline Online & as recorded in February, 2014 and minimum $(2.36 \mathrm{mg} / \mathrm{l})$ in November, 2012. The value of \\
\hline 04.09.2015 & 012 and 55.17 (J uly) to 87.49 (February) in 2013-14 with regular trends in fluctuation. Mean \\
\hline Key words & secchi disc reading varied from $1.94 \pm .57 \mathrm{~m}$ in $2012-13$ and $2.02 \pm 0.40 \mathrm{~m}$ in $2013-14$. Dissolved \\
\hline id fishery & oxygen was found to vary from 6.10 (February) to 6.80 (November) during 2012, 3.90 \\
\hline Water chemistry & \\
\hline Kaptai Lake & for one year study. The present research provides baseline information on changing trends of \\
\hline Bangladesh & $\begin{array}{l}\text { physicochemical parameters of Kaptai Lake which will facilitate sustainable management and } \\
\text { conservation of this lake ecosystem. }\end{array}$ \\
\hline
\end{tabular}

To cite this article: MA Bashar, SS Basak, KB Uddin, AKMS Islam and Y Mahmud, 2015. Changing trends of physicochemical parameters in Kaptai lake of Bangladesh. Res. Agric. Livest. Fish. 2 (2): 319-327.

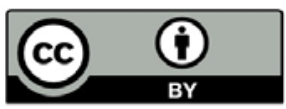

This is an open access article licensed under the terms of the Creative Commons Attribution 4.0 International License

www.agroaid-bd.org/ralf, E-mail: editor.ralf@gmail.com 


\section{INTRODUCTION}

Kaptai Lake is one of the most important freshwater bodies which are considered as the largest manmade freshwater resource in the South-East Asia including Bangladesh (Halder et al. 1991). The Kaptai Lake was basically created for hydro-electrical power generation by damming the river Karnaphuli near Kaptai of Rangamati district in 1961. Total surface area of this lake is 68,800 hectare and average water depth is about 9 meters with maximum depth of 32 meters (Halder et al. 1991, Alamgir and Ahmed, 2008). The shoreline and basin of this water body are very irregular (Halder et al. 1991). Although this lake was primarily created for power generation, it contributes to produce significant quantity of freshwater fishes, navigation, and flood control. Moreover, the water of this lakes is also been used for many activities namely; households, agriculture, boat repairing and fishing that may result in the pollution of the lake environment.

Commercial fishing in this lake started with 1200 metric tons in 1965/66 and has reached up to 8,248 metric tons at present (DoF, 2014). However, the recent contribution of Kaptai lake fisheries is largely limited with unwanted species. The most valuable major carp species (Labeo rohita, Catla catla, Cirrhinus cirrhosus, Labeo calbasu and Tor tor) have declined devastatingly from the initial 81\% as recorded in 1965/66 to about $5 \%$ at present (Alamgir and Ahmed, 2008). The low valued small forager fish (e.g., Corica soborna, Gonialosa spp., Ompok pabda) have boomed from the initial 3\% in 1965/66 to about 92\% now (Alamgir and Ahmed, 2008). Aquatic Research Group (ARG) (1986) recorded 49 indigenous fish species and 5 exotic fishes in this lake, Halder et al (1991) recorded a total of 71 fish species including 5 exotic fishes and 2 species of prawn. Chakma (2007) documented that 74 freshwater fish species and 2 prawn species are available in the Kaptai Lake.

Additionally, the limnological parameters of this lake were also studied by many researchers. For example, Sandercock (1966) documented the limnological parameters and phytoplankton of this lake, Chowdhury (1980), Chowdhury and Mazumder (1981), Chowdhury and Khair (1982) and ARG (1986) described the hydrobiology of this lake. Nevertheless, Jenkins (1985) suggested a long-term research program in order to sustainable management of the lake ecosystem. Thereafter, Rahman (1988) reported the morphometric details of the reservoir and Halder et al (1991) and Bashar et al (2015) described the limnology and primary production of Kaptai Lake. However these researches were also conducted for a short period of time. Therefore the aim of the study was to elucidate the changing trends of physicochemical parameters of this lake over a period of two years. The data obtained from this study can be used as baseline information for preparing a management decision of this important freshwater Lake Ecosystem of Bangladesh.

\section{MATERIALS AND METHODS}

The study was conducted in Kaptai Lake the Southeastern Part of Bangladesh from July 2012 to June 2014. Five sampling stations of this lake namely; Rangamati Sadar, Kaptai, Barkal, Langadhu and Naniarchar Upazilla were selected taking into consideration: (i) the following streams and drainage arms, (ii) their catchment area, and (iii) shallow, medium and deep water levels of the lake. Water samples for physicochemical parameters were collected fortnightly from each sampling station with water sampler bottle during morning between 8.30 to $10.30 \mathrm{a}$.m. Air and water temperature were recorded at the sampling sites whereas the others were recorded in the laboratory. Temperature of water and air were recorded by a centigrade thermometer. Water transparency was measured through secchi disc reading. Dissolved Oxygen, $\mathrm{pH}$, free $\mathrm{CO}_{2}$, total alkalinity, total hardness of water were measured by using $\mathrm{HACH}$ water testing kit (Model: FF-3, USA). Rainfall and water depth were collected from Power Development Board (PDB) at Kaptai office, Rangamati district, Bangladesh.

Statistical analysis were applied to find out the standard deviation of different parameters in different months and to determine the extent of correlation amongst different parameters. Correlation was calculated by using SPSS ${ }^{\circledR}$ (Version 11.5, 2007. Systat, inc. USA), a computer based programme for windows ${ }^{\circledR}$. 


\section{RESULTS AND DISCUSSION}

Monthly fluctuations, annual range, mean and standard deviation ( \pm SD) of different physicochemical parameters and their relationships are presented in Tables 1 and 2 . The highest air temperature $\left(31.52^{\circ} \mathrm{C}\right)$ was recorded in September, 2013 and the lowest $\left(21.04^{\circ} \mathrm{C}\right)$ in January, 2014 with a mean of $27.30 \pm 1.70^{\circ} \mathrm{C}$. The maximum water temperature $\left(30.38^{\circ} \mathrm{C}\right)$ was recorded in September, 2013 and minimum $\left(20.42^{\circ} \mathrm{C}\right)$ in January, 2014 (with a mean of $26.47 \pm 1.64^{\circ} \mathrm{C}$ ) which is acceptable range for fish production (Table 1). The water temperature values naturally, showed close relationship with the air temperature $(r=0.998$, Table 2), high during the hot summer season (June-July) and lower during winter months (December-January). A similar correlation with air and water temperature was also reported by Chowdhury and Mazumder (1981) and Rahman et al (2014).

The $\mathrm{pH}$ of water was found to alkaline in nature (6.9 to 8.20 , Table 1), showed positive correlation with free $\mathrm{CO}_{2}(\mathrm{r}=0.537$, Table 2). Present observation close to observation of Ahmed et al (1993) and Rahman et al (2014). But differ considerably with Chowdhury and Mazumder (1981), who reported a $\mathrm{P}^{\mathrm{H}}$ range of 5.31-6.32. The free carbon dioxide in water forms carbonic acid $\left(\mathrm{H}_{2} \mathrm{CO}_{3}\right)$ resulting change in the $\mathrm{P}^{\mathrm{H}}$ as the hydrogen ions are set free after dissociation (Krishna Swarup and Singh, 1979). The high values may be due to attributed sewage discharged by surrounding city and agricultural fields (Medudhula Thirupathaiah and Samatha Sammaiah, 2012).

Free $\mathrm{CO}_{2}$ ranged between 2.36 to $7.81 \mathrm{mg} / \mathrm{l}$. The maximum $(7.81 \mathrm{mg} / \mathrm{l})$ value was recorded in February, 2014 and minimum $(2.36 \mathrm{mg} / \mathrm{l})$ in November, 2012, showed inverse correlation with dissolved oxygen ( $r=-$ 0.504 , Table 1 and 2). The increase of free $\mathrm{CO}_{2}$ concentration was a consequence of increasing trend in water level due to the influx from rain water of hill streams (Ahmed et al 1993). In the present investigation, the low free $\mathrm{CO}_{2}$ content in November, 2012 was possibly due to low rainfall which caused low decomposition of organic matter and high photosynthesis which consumed free $\mathrm{CO}_{2}$ (Kabir and Naser 2011; Rahman et al 2014).

The highest total alkalinity value was recorded in December $(90.68 \mathrm{mg} / \mathrm{l}) 2013$ and the lowest $(51.9 \mathrm{mg} / \mathrm{l})$ in December 2012, showed a positive correlation with total hardness ( $r=0.52$, Table 1 and 2). Wurts and Durborow (1992) reported that most aquatic organisms can live in a broad range of alkalinity concentrations and desired total alkalinity level for most aquaculture species lies between $50-150 \mathrm{mg} / \mathrm{l} \mathrm{CaCO}$, but no less than $20 \mathrm{mg} / \mathrm{l}$. Jhingran (1989) observed that alkalinity values of more than $50 \mathrm{mg} / \mathrm{l}$ are most productive and those of less than $10 \mathrm{mg} / \mathrm{l}$ do not produce sufficient crops. He added that total alkalinity values of up to $20 \mathrm{mg} / \mathrm{l}$ indicate poor production, 40-90 mg/l show medium production and values above $90 \mathrm{mg} / \mathrm{l}$ show high production. Total alkalinity value of over $80 \mathrm{mg} / \mathrm{l}$ indicates a lake to be nutrient rich and of hard water type and such waters are often the best fish producers (Barrett, 1953). In the present investigation total alkalinity indicates Kaptai Lake may be regarded as medium productive lake. Similar finding was also observed by Ahmed et al (1992) and Rahman et al (2014).

Hardness is also important to aquaculture. Calcium and magnesium are the most common sources of water hardness. Calcium and magnesium are essential in the biological processes of aquatic animals, especially for bone and scale formation in fish (Wurts and Durborow, 1992). Hardness of lake water varied from 37.8 (August) to 47.3 (November) in 2012 and 55.17 (July) to 87.49 (February) in 2013-14 with regular trends in fluctuation (Fig. 1). Present findings differ considerably with Ahmed et al 1993, who reported hardness of lake water varied from 35.33 (August) to 54.72 (February) in 1988-89, 45.5 (April) to 58.14 (May) in 1989-90 and 47.6 (September) to 65.0 (January) in 1990-91. Chowdhury and Mazumder (1981) reported a narrow range of hardness $(50.00-66.67 \mathrm{mg} / \mathrm{l})$ from the same reservoir.

Total hardness showed an inverse correlation with rainfall $(r=-0.586, p<0.05)$ and positive correlation with $\mathrm{P}^{\mathrm{H}}(r=0.803, p<0.01)$ and transparency $(r=0.854, p<0.01)$ (Table 2). More or less similar findings observed by Ahmed et al (1993) who cited total hardness showed an inverse correlation with rainfall $(r=-0.408, p<0.02)$ and positive correlation with $\mathrm{P}^{\mathrm{H}}(\mathrm{r}=0.386, \mathrm{p}<0.02)$ and secchi disc transparency $(r=0.409, p<0.01)$. The present study differ with reference statement as value of present parameter significantly increasing trend in lake water due to unplanned agricultural and human activities. 
Table 1. Monthly fluctuation of different physicochemical parameters in Kaptai Lake, Bangladesh collected from the year $2012-2014$.

\begin{tabular}{|c|c|c|c|c|c|c|c|c|c|c|c|c|c|c|}
\hline \multirow{2}{*}{ Parameters } & \multicolumn{6}{|c|}{2012} & \multicolumn{6}{|c|}{2013} & \multirow{2}{*}{ Rang } & \multirow{2}{*}{ Mean \pm SD } \\
\hline & Jul & Aug & Sep & Oct & Nov & Dec & Jan & Feb & Mar & Apr & May & Jun & & \\
\hline Air $\operatorname{Tem}^{\circ} \mathrm{C}$ & 29.02 & 30.8 & 30.7 & 30.5 & 27.4 & 24.0 & 23.1 & 23.2 & 26.6 & 27.7 & 30.5 & 30.9 & $24.0-30.9$ & $27.97 \pm 3.08$ \\
\hline Water $\operatorname{Tem}^{\circ} \mathrm{C}$ & 32.8 & 29.1 & 29.1 & 28.8 & 26.1 & 25.1 & 21.1 & 22.6 & 24.8 & 26.3 & 28.9 & 29.2 & 21.1-32.8 & $27.09 \pm 5.89$ \\
\hline $\mathrm{pH}$ & 6.9 & 7.1 & 7.0 & 7.2 & 7.1 & 7.4 & 6.9 & 7.5 & 7.5 & 7.2 & 7.6 & 7.3 & $6.9-7.6$ & $7.6 \pm 0.52$ \\
\hline $\mathrm{CO} 2(\mathrm{mg} / \mathrm{l})$ & 3.12 & 2.95 & 2.45 & 2.93 & 2.36 & 2.63 & 3.04 & 2.99 & 2.99 & 3.19 & 3.32 & 3.13 & $2.36-3.32$ & $2.92 \pm 0.60$ \\
\hline T. A. $(\mathrm{mg} / \mathrm{l})$ & 62.6 & 54.6 & 58.2 & 59.1 & 60.2 & 51.9 & 61.8 & 61.4 & 65.2 & 61.6 & 56.9 & 57.4 & $51.9-65.2$ & $59.45 \pm 6.71$ \\
\hline T. H (mg/l) & 44.5 & 37.8 & 43.5 & 42.3 & 47.3 & 43.9 & 43.9 & 44.8 & 40.8 & 43.3 & 41.9 & 42.5 & $37.8-47.3$ & $43.08 \pm 5.51$ \\
\hline Trans (m) & 0.97 & 1.7 & 1.6 & 2.06 & 2.04 & 2.09 & 2.29 & 2.25 & 2.05 & 2.43 & 2.25 & 1.62 & $0.97-2.43$ & $1.94 \pm .57$ \\
\hline DO (mg/l) & 6.68 & 6.34 & 6.52 & 6.53 & 6.80 & 6.34 & 6.20 & 6.10 & 6.42 & 6.40 & 6.49 & 6.10 & $6.10-6.80$ & $6.4 \pm 1.51$ \\
\hline
\end{tabular}

(TA = Total alkalinity, $\mathrm{TH}=$ Total Hardness, Trans = Transparency $)$ 
Table 1. Monthly fluctuation of different physicochemical parameters in Kaptai Lake, Bangladesh collected from the year $2012-2014$ (contd.).

\begin{tabular}{|c|c|c|c|c|c|c|c|c|c|c|c|c|c|c|}
\hline \multirow{2}{*}{ Parameters } & \multicolumn{6}{|c|}{2013} & \multicolumn{6}{|c|}{2014} & \multirow{2}{*}{ Range } & \multirow{2}{*}{ Mean $\pm S D$} \\
\hline & Jul & Aug & Sep & Oct & Nov & Dec & Jan & Feb & Mar & Apr & May & June & & \\
\hline Air $\operatorname{Tem}^{\circ} \mathrm{C}$ & 29.01 & 30.70 & 31.52 & 30.54 & 22.33 & 23.35 & 21.04 & 23.79 & 27.12 & 27.49 & 30.19 & 30.58 & $21.04-31.52$ & $27.30 \pm 1.70$ \\
\hline Water $\operatorname{Tem}^{\circ} \mathrm{C}$ & 27.90 & 29.88 & 30.38 & 29.59 & 21.54 & 23.10 & 20.42 & 23.08 & 26.04 & 26.55 & 29.21 & 29.99 & $20.42-30.38$ & $26.47 \pm 1.64$ \\
\hline$P^{H}$ & 7.17 & 7.17 & 7.08 & 7.22 & 7.36 & 7.50 & 8.20 & 7.68 & 7.55 & 7.69 & 7.60 & 7.65 & $7.08-8.20$ & $7.49 \pm 0.37$ \\
\hline $\mathrm{CO} 2(\mathrm{mg} / \mathrm{l})$ & 4.45 & 4.25 & 3.86 & 3.89 & 3.88 & 3.32 & 5.33 & 7.81 & 7.15 & 5.99 & 5.56 & 6.14 & $3.32-7.81$ & $5.14 \pm 1.48$ \\
\hline T. A. (mg/l) & 64.91 & 67.36 & 71.97 & 70.96 & 82.21 & 90.68 & 90.32 & 81.32 & 68.93 & 68.31 & 70.77 & 71.98 & 64.91-90.68 & $74.97 \pm 9.69$ \\
\hline T. H. (mg/l) & 55.17 & 60.60 & 60.99 & 65.47 & 65.24 & 79.88 & 81.34 & 87.49 & 75.63 & 77.09 & 82.73 & 74.26 & $55.17-87.49$ & $72.16 \pm 12.2$ \\
\hline Trans (m) & 1.20 & 1.70 & 1.65 & 1.90 & 2.04 & 2.13 & 2.39 & 2.46 & 2.07 & 2.61 & 2.36 & 1.72 & $1.20-2.61$ & $2.02 \pm 0.40$ \\
\hline DO (mg/l) & 6.38 & 6.33 & 6.14 & 6.13 & 5.35 & 5.50 & 5.33 & 3.90 & 5.55 & 6.02 & 5.91 & 6.33 & $3.90-6.38$ & $5.74 \pm 0.68$ \\
\hline Water depth (m) & 11.76 & 9.14 & 7.20 & 7.33 & 6.90 & 6.43 & 7.89 & 5.68 & 6.78 & 4.39 & 11.04 & 11.02 & $4.39-11.76$ & $7.96 \pm 2.56$ \\
\hline Rainfall (mm) & 19.25 & 6.58 & 24.58 & 17.33 & 0.00 & 0.00 & 0.00 & 1.67 & 7.33 & 8.42 & 13.00 & 8.67 & $0.00-24.58$ & $8.90 \pm 9.71$ \\
\hline
\end{tabular}

( $\mathrm{T} . \mathrm{A} .=$ Total alkalinity, $\mathrm{T} . \mathrm{H}=$ Total Hardness, Trans = Transparency) 


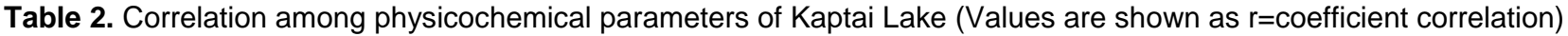

\begin{tabular}{|c|c|c|c|c|c|c|c|c|c|c|}
\hline \multicolumn{11}{|c|}{ 2012-2014 } \\
\hline Parameters & $\begin{array}{l}\text { Air tem } \\
{ }^{\circ} \mathrm{C}\end{array}$ & $\begin{array}{l}\text { Water } \\
\text { tem }{ }^{\circ} \mathrm{C}\end{array}$ & $\begin{array}{l}\text { DO } \\
\text { (mg/l) }\end{array}$ & $\begin{array}{l}\text { Free CO2 } \\
(\mathrm{mg} / \mathrm{l})\end{array}$ & $\begin{array}{l}\text { T. H. } \\
\text { (mg/l) }\end{array}$ & $\begin{array}{l}\text { T. A. } \\
\text { (mg/l) }\end{array}$ & $\mathrm{PH}$ & $\begin{array}{l}\text { Trans } \\
\text { (m) }\end{array}$ & $\begin{array}{l}\text { Water depth } \\
\text { (m) }\end{array}$ & $\begin{array}{l}\text { Rainfall } \\
(\mathrm{mm})\end{array}$ \\
\hline Air tem ${ }^{\circ} \mathrm{C}$ & 1 & $.998^{\star \star}$ & $.716^{\star \star}$ & -0.11 & -0.487 & $-.842^{\star \star}$ & $-.610^{*}$ & -0.521 & 0.459 & $.816^{\star \star}$ \\
\hline $\begin{array}{l}\text { Water } \\
\text { tem }{ }^{\circ} \mathrm{C}\end{array}$ & $.998^{\star *}$ & 1 & $.719 * \star$ & -0.122 & -0.471 & $-.818^{\star \star}$ & $-.601^{*}$ & -0.52 & 0.465 & $.794^{\star *}$ \\
\hline DO (mg/l) & $.716^{\star \star}$ & $.719 * \star$ & 1 & -0.504 & $-.660^{\star}$ & $-.610^{*}$ & -0.457 & $-.599^{\star}$ & 0.518 & $.607^{*}$ \\
\hline $\begin{array}{l}\text { Free CO2 } \\
(\mathrm{mg} / \mathrm{l})\end{array}$ & -0.11 & -0.122 & -0.504 & 1 & $.615^{\star}$ & -0.128 & 0.537 & 0.459 & -0.136 & -0.243 \\
\hline T. H. $(\mathrm{mg} / \mathrm{l})$ & -0.487 & -0.471 & $-.660^{\star}$ & $.615^{\star}$ & 1 & 0.52 & $.803^{\star \star}$ & $.854^{\star \star}$ & -0.337 & $-.586^{\star}$ \\
\hline T. A.(mg/l) & $-.842^{\star \star}$ & $-.818^{\star \star}$ & $-.610^{*}$ & -0.128 & 0.52 & 1 & 0.543 & 0.449 & -0.359 & $-.697^{\star}$ \\
\hline $\mathrm{PH}$ & $-.610^{\star}$ & $-.601^{*}$ & -0.457 & 0.537 & $.803^{\star *}$ & 0.543 & 1 & $.714^{\star *}$ & -0.179 & $-.624^{*}$ \\
\hline Trans (m) & -0.521 & -0.52 & $-.599 *$ & 0.459 & $.854^{\star \star}$ & 0.449 & $.714^{\star \star}$ & 1 & $-.619^{\star}$ & -0.574 \\
\hline \multicolumn{11}{|c|}{ 2013-2014 } \\
\hline $\begin{array}{l}\text { Water depth } \\
\text { (m) }\end{array}$ & 0.459 & 0.465 & 0.518 & -0.136 & -0.337 & -0.359 & -0.179 & $-.619^{\star}$ & 1 & 0.361 \\
\hline $\begin{array}{l}\text { Rainfall } \\
(\mathrm{mm})\end{array}$ & $.816^{\star \star}$ & $.794^{\star *}$ & $.607^{\star}$ & -0.243 & $-.586^{\star}$ & $-.697^{\star}$ & $-.624^{\star}$ & -0.574 & 0.361 & 1 \\
\hline
\end{tabular}

** Correlation is significant at the 0.01 level. * Correlation is significant at the 0.05 level. 


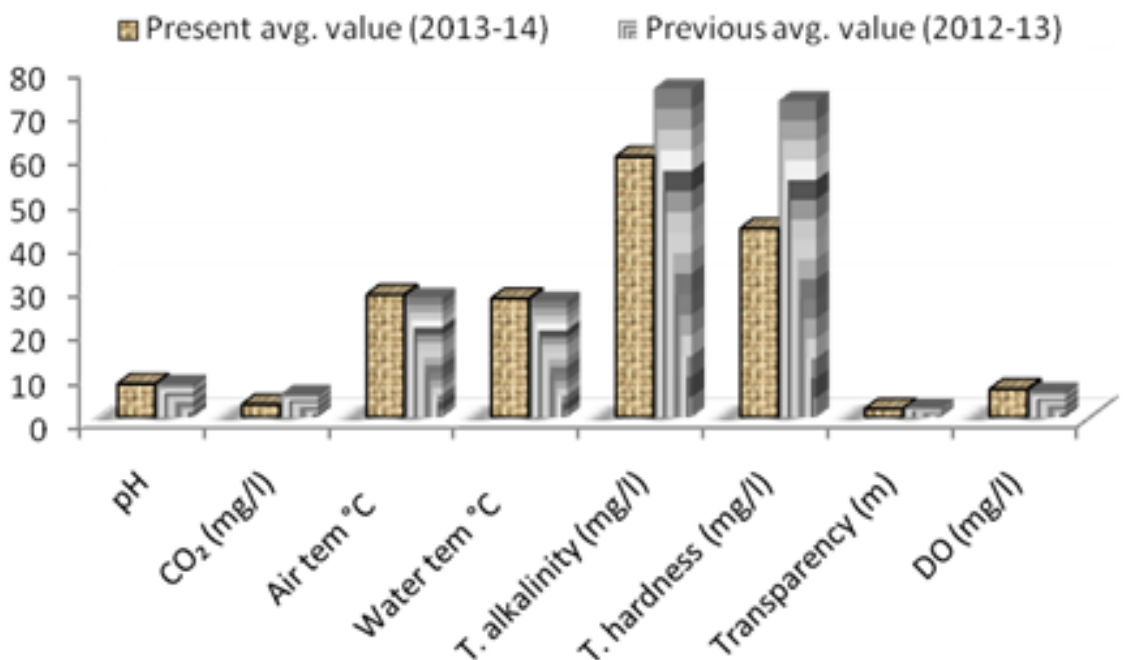

Figure 1. Changing trends of different physicochemical parameters of Kaptai Lake, Bangladesh from 2012-14

Transparency of water high in the lake, mean secchi disc reading varied from $1.94 \pm .57 \mathrm{~m}$ in $2012-13$ and $2.02 \pm 0.40 \mathrm{~m}$ in 2013-14. The limit of secchi disc visibility was found to fluctuate between 0.97 (July) and 2.43 $\mathrm{m}$ (April) during 2012-13 and between $1.20 \mathrm{~m}$ (July) and $2.61 \mathrm{~m}$ (April) during 2013-14. The limit of visibility at all station during the winter months was higher whereas, lower visibility prevailed during the monsoon months. More or less same finding observed by Ahmed et al (1993), he reported during monsoon water transparency is reduced considerably as a result of huge load of suspended silt and other materials carried by the inflow of hilly streams and the suspension of bottom deposits due to heavy rain and gusty wind action. On the other hand, absence of rain, gusty wind and low discharge from hilly streams the water became clearer during post monsoon, pre-winter and winter months. He also reported, clarity of water was high in the reservoir, mean secchi disc reading being 2.05 $\pm 1.17,2.52 \pm 0.70$ and 2.40 $\pm 0.73 \mathrm{~m}$ during 1988-89, 1989-90 and 1990-91. Bashar et al (2014) observed, transparency of water in lake were within permissible limits for aquatic organisms. Moreover, they also documented water transparency ranged from 0.98 to $2.38 \mathrm{~m}$ in creeks as well as lake areas. Water transparency showed inverse relationship with rainfall $(r=-0.574)$ and water depth $(r=-$ $0.619, p<0.05)$, but positive correlation with total hardness $(r=0.854, p<0.01)$ and $\mathrm{P}^{\mathrm{H}}(r=0.714, p<0.01)$. Chowdhury and Mazumder (1981) and ARG (1986) also reported the occurrence of high turbidity in the lake during the monsoon period. Similar observation was made by Rahman et al (2014).

Dissolved oxygen is an important aquatic parameter, whose is vital to aquatic fauna. Water at surface level was always well oxygenated and congenial for aquatic life. The mean dissolved oxygen concentration was $6.4 \pm 1.51$ and $5.74 \pm 0.68 \mathrm{mg} / \mathrm{l}$ during $2012-13$ and 2013-14. It ranged from 6.10 (February) to 6.80 (November) during 2012, 3.90 (February) to $6.38 \mathrm{mg} / \mathrm{l}$ (July) during 2013-14. No marked variation in dissolved oxygen content among different study point was observed in first year but slightly change was observed in second year. Rani et al (2004) reported lower values of dissolved oxygen in summer season due to higher rate of decomposition of organic matter and limited flow of water in low holding environment due to high temperature. The findings of present study can also be compared with the previous findings, reported for River Osun (Welcomme, 1985), Zambezi River (Hall et al 1977) Qua Iboe River (Akpan and Offem, 1993) who observed that tropical African aquatic systems generally have low DO in dry season than the wet season. Rahman et al (2014) reported that seasonal trends of dissolved oxygen were found warmer months and lower values during winter months.

Present study revealed positive correlation of DO with air temperature $(r=0.716, p<0.01)$, water temperature $(r=0.719, p<0.01)$ and rainfall $(r=0.607, p<0.05)$ but inverse relationship with free $\mathrm{CO}_{2}(r=-0.504)$, total hardness $(r=-0.660, p<0.05)$, total alkalinity $(r=-0.610, p<0.01)$, transparency $(r=-0.599, p<0.01)$ and $P^{H}$ $(r=-0.457)$ (Table 2). Similar statement was also recorded by Ahmed et al (1993). Hussainy (1967) opined that in tropical lakes temperatures is of great significance in determining the trend of DO concentration but no significant correlation could be established between DO concentration and water temperature. 
The maximum rainfall was recorded in September $(24.58 \mathrm{~mm})$. No rainfall was recorded during November, December and January of 2013-14, showed inverse correlation with total hardness $(r=-0.586$, $p<0.05)$, total alkalinity $(r=-0.697, p<0.05)$ and $\mathrm{P}^{\mathrm{H}}(\mathrm{r}=-0.624, \mathrm{p}<0.05)$ but positive relationship with air temperature $(r=0.816, p<0.01)$, water temperature $(r=0.794, p<0.01)$ and $D O(r=0.607, p<0.05)($ Table 1 and 2). Similar findings were made by Ahmed et al (1993). He reported no rainfall was recorded during November, December, January and March of 1988-89; December and January of 1989-90 and January 1990-91. No conclusions could be drawn from this study as rainfall values were recorded only one year from July 2013 to June 2014. Water depth was found to fluctuate from the minimum of $4.39 \mathrm{~m}$ to the maximum of $11.76 \mathrm{~m}$ with mean value of $(7.96 \pm 2.56 \mathrm{~m}$, Table 1$)$, showed inverse correlation with total hardness $(r=-0.337)$, total alkalinity $(r=-0.359), \mathrm{P}^{\mathrm{H}}(\mathrm{r}=-0.179)$ and transparency $(r=-0.619, p<0.05)$ but positive relationship with air temperature $(r=0.459)$, water temperature $(r=0.465)$ and DO $(r=0.518)$ (Table 2).

\section{Changing trends of physicochemical parameters}

The data obtained from this study revealed that the physicochemical parameters of the Kaptai Lake are comparatively in well condition but narrow variation existed in total hardness (43.08 $55.51 \mathrm{mg} / \mathrm{l}$ in 2012-13, $72.16 \pm 12.24 \mathrm{mg} / \mathrm{l}$ in 2013-14) and total alkalinity $(59.45 \pm 6.71 \mathrm{mg} / \mathrm{l}$ in $2012-13,74.97 \pm 9.69 \mathrm{mg} / \mathrm{l}$ in 2013-14) (Table 1 \& Fig 1). Hardness is caused by compounds of calcium and magnesium and by a variety of other metals. General guidelines for classification of waters are-0 to $60 \mathrm{mg} / \mathrm{l}$ as calcium carbonate is classified as soft, 61 to $120 \mathrm{mg} / \mathrm{l}$ as moderately hard, 121 to $180 \mathrm{mg} / \mathrm{l}$ as hard and more than $180 \mathrm{mg} / \mathrm{l}$ as very hard (Wurts and Durborow, 1992). The present study reveals that mean values of hardness were in the soft to moderate hard categories. Similar findings observed by Ahmed et al (1993), he reported that Kaptai lake can be regarded as a medium productive lake taking into consideration total hardness ranged from 35.33 to 65.0 $\mathrm{mg} / \mathrm{l}$. Total alkalinity is the total concentration of bases in water. These bases are usually bicarbonates $\left(\mathrm{HCO}_{3}\right)$ and carbonates $\left(\mathrm{CO}_{3}\right)$ and they act as a buffer system that prevents drastic changes in $\mathrm{pH}$. Large daily changes in $\mathrm{P}^{\mathrm{H}}$ can cause stress, poor growth and even death of the farmed animals (Wurts and Durborow 1992). The present investigation showed that the total alkalinity was found to fluctuate but acceptable range. Compare the total hardness and total alkalinity regular fluctuate occurred due to increase of human population, indiscriminate use of agro-chemicals and fertilizers in the lakeside of cultivable lands.

\section{CONCLUSION}

The present study is baseline study on changing trends of physicochemical parameters of the Kaptai Lake which will prove effective in case of Lake Ecosystem management and conservation. The findings of the present study will be helpful for the future researcher to work on these aspects and replace the discrete data about water quality parameter of Kaptai Lake and establish a crystal clear and precise document explaining variation and inter-relation among different physicochemical parameters of Kaptai Lake.

\section{ACKNOWLEDGEMENT}

The authors are grateful to fish Production, Conservation and Strengthening Management at Kaptai Lake (Component C: BFRI Part) Project for financial assistance.

\section{REFERENCES}

1. Ahmed KK, GC Halder and SB Saha, 1993. Limnological studies on Kaptai Lake. Final report. Fisheries Research Institute, Mymensingh-2201, BANGLADESH. PP. Vii+36.Akpan ER and Offem JO. 1993. Seasonal variation in water quality of the Cross River, Nigeria. Rev. Hydrobiol. Trop. 26: 95-103.

2. Alamgir M and SU Ahmed, 2008. Sustainable Management Techniques of Kaptai Lake Fisheries. BFRI, Mymensingh. 71p. Aquatic Research Group (University of Chittagong, Bangladesh), 1986. Hydrobiology of the Kaptai reservoir. FAO, Rome, Italy. FAO/UNDP Final Report. DP/BGD/79/015-4/FI, 192 pp.

3. Bashar MA, SS Basak, KB Uddin, AKM Saiful Islam, Y Mahmud, MP Goutham-Bharathi and KD Simon, 2014. Development of Indian Major Carp Fry Raising Techniques in Creeks of Kaptai Lake, Bangladesh. World Journal of Fish and Marine Sciences, 6: 532-536. 
4. Bashar MA, SS Basak, KB Uddin, AKM Saiful Islam and Y Mahmud, 2015. Seasonal Variation of Zooplankton Population with Reference to Water Quality of Kaptai Lake, Bangladesh. Bangladesh Research Publications Journal, 11: 127-133.

5. Brett JR, 1979: Environmental factors and growth. In: W.S. Hoar, D.J. Randall and J.R. Brett (Eds.), Fish Physiology, Environmental relations and behavior, Academic Press, New York: 599-677.

6. Chakma IL, 2007. Fish Culture in Hill Tract Regions, Desio Projatir Matshya Sakgrakkhon O Shamprasaran Ovijan 2007, Department of Fisheries, Ministry of Fisheries and Livestock, Dhaka, p. 68.

7. Chowdhury SC, 1980. A preliminary report on the phytoplankton of Kaptai Lak with reference to some physico-chemical factors. University of Chittagong, Chittagong, Bangladesh. M Sc thesis, $97 \mathrm{pp}$.

8. Chowdhury SC, Khair A, 1982. The phytoplankton members of Kaptai Lake, Chittagong Hill Tracts-I: Desmidiaceae. University of Chittagong, Chittagong, Bangladesh. Chittagong University Sudies Part II, 6: 129-136.

9. Chowdhury SH, Mazumder A, 1981. Limnology of Lake Kaptai-I: Physico-chemical features. Bangladesh Journal of Zoology, 9: 59-72.

10. DoF, 2009. Fish week Compendium, Department of Fisheries, Ministry of Fisheries and Livestock. Bangladesh.

11. Halder GC, MA Mazid, KI Haque, S Huda and KK Ahmed, 1991. A Review of the Fishing Fauna of Kaptai Reservoir. Bangladesh Journal of Fisheries, 14: 127-135.

12. Hall A, Valente IMC and Davies B, 1977. The Zambezi River in Mozambique: The physico-chemical Status of the middle and lower Zambezi Prior to the closure of the Cubora Bassa Dam. Freshwater Biology, 7: 187-206.

13. Hussainy SV, 1967. Studies on the limnology and primary production of a tropical lake. Hydrobiology, 30: 335-352.

14. Jenkins RM, 1985. Final report on the planning, implementation and follow-up activities associated with the survey of fishery management of Kaptai Lake conducted by the Aquatic Research Group. University of Chittagong, Chittagong, Bangladesh. 7p.

15. Jhingran AG, 1989. Reservoir Fisheries Management in India. Central Inland Capture Fisheries Research Institute, Barrackpore, West Bengal, India. Bull No. 45: 65 PP.

16. Kabir AKMN and Naser MN, 2011. Physico-chemical aspects of CHANDBILL oxbow lake of Meherpur, Bangladesh. Dhaka Univ. Journal of Biological Science, 20: 31-39.

17. Swarup K and SR Singh, 1979. Limnological studies of Suraha lake (BALLIA) I. Variations in the water quality. Journal of Inland Fisheries and Sociology, India, 11: 22-23.

18. Thirupathaiah M and Ch. S Sammaiah, 2012. Analysis of water quality using physico-chemical parameters in lower manair reservoir of Karimnagar district, Andhra Pradesh. International Journal of Environmental Science, 3: 172-175.

19. Rahamam MA, 1988. The need for reservoir fishery management in Bangladesh. In De Silva, S.S., ed., Reservoir fishery management in Asia: proceedings of a workshop held in Kathmandu, Nepal, 23-28 November 1987. IDRC, Ottawa, ON, Canada. IDRC-264e, 164-168.

20. Rahman MM, MA Bashar, Z Farhana and MY Hossain, 2014. Temporal Variation of Physicochemical Parameters in Kaptai Lake, Bangladesh. World Journal of Fish and Marine Sciences, 6: 475-478.

21. Rani R, Gupta BK and Srivastava KBL, 2004. Studies on water quality assessment in Satna city (M.P): Seasonal parametric variations, Nature environment and pollution technology, 3: 563-565.

22. Sandercock FK, 1966. Chittagong hill tracts soil and land use survey, 1964-65 volume 4: Fisheries. East Pakistan Agricultures Development Corporation, Pakistan. Canadian Colombo Plan Project F475, 67p.

23. Welcome RL, 1985. River Fisheries. FAO Fish. Tech. Pap, 262-330 p.

24. Wurts WA and RM Durborow, 1992. Interactions of $\mathrm{pH}$, carbon dioxide, alkalinity and hardness in fish ponds. Southern Regional Aquaculture Center, Publication No. 464. 